\section{EREM 76/4}

Journal of Environmental Research, Engineering and Management

Vol. 76 / No. 4 / 2020

pp. $106-117$

DOI 10.5755/j01.erem.76.4.26665
Assessment of the Environmental Carrying Capacity for Protected Areas: A Study of Petrified Forest and Hassanah Dome, the Great Cairo

\begin{tabular}{l|l} 
Received 2020/06 & Accepted after revision 2020/10
\end{tabular}

\title{
Assessment of the Environmental Carrying Capacity for Protected Areas: A Study of Petrified Forest and Hassanah Dome, the Great Cairo
}

\section{Ibrahim Moukhtar*}

Environmental Planning Department, Faculty of Urban and Regional Planning, Cairo University, Ph.D. Researcher, Cairo University Campus, Gamaa Street, Giza, Egypt

\section{Abdelkhalek A. Ibrahim}

Urban Planning Department, Faculty of Urban and Regional Planning, Cairo University, Associate Professor of Sustainable Urban Development, Cairo University Campus, Gamaa Street, Giza, Egypt.

\section{Tarek Abou El Seoud}

Environmental Planning Department, Faculty of Urban and Regional Planning, Cairo University, Professor Dr of Environmental Planning and Geo informatics, Cairo University Campus, Gamaa Street, Giza, Egypt

\section{Seham Mostafa}

Environmental Planning Department, Faculty of Urban and Regional Planning, Cairo University, Lecturer of Environmental Management; analysis \& assessment, Cairo University Campus, Gamaa Street, Giza, Egypt

*Corresponding author: Ibrahim.Moukhtar1991@gmail.com

The research aims to quantify the environmental carrying capacity of both Petrified Forest Protectorate in East Greater Cairo and Hassanah Dome Protectorate in West Greater Cairo, with their sustainable use and preservation. The environmental carrying capacity works as a sustainable method not to exceed the environmental limits of nature reserves or in other words, the number of visitors does not exceed the maximum allowed for visiting the 
reserve. The methodology used in the International Union for Conservation of Nature (IUCN) has been used. The elements of the methodology are at 3 levels, namely, physical carrying capacity (PCC), which depends on the optimal rate of space used per capita and open period, real carrying capacity (RCC), which depends on environmental and social factors, and effective carrying capacity (ECC), which depends on administrative and operational capacity. The results of the research found that the Petrified Forest Protectorate (East of Greater Cairo) accommodates 186,286 visitor per day, and Hassanah Dome Protectorate (West of Greater Cairo) accommodates 26,612 visitor per day. In addition to assessing the level of the ecological carrying capacity index $(\mathrm{ECCl})$, which measures the extent of support for the population and its activities, and by comparing the total environmental carrying capacity of the two protectorates that reached 212,898 visitors per day with the population of Greater Cairo (Cairo Governorate and Giza Governorate), which reached 17 million (Capmas, 2017), it was found that the environmental carrying capacity of the two protectorates is not sufficient to support recreational activities and environmental tourism for people of Greater Cairo.

Keywords: carrying capacity, sustainability, environmental management, protected areas, ecotourism.

\section{Introduction}

The research problem is represented in the urban growth and population pressure in the Greater Cairo region, and the fact that Cairo is the capital of the Arab Republic of Egypt and the largest in the population, as the population of the Greater Cairo Region (Giza Governorate and Cairo Governorate) reached 17 million people (Capmas, 2017). With the increase in the need to provide recreational and tourism areas, the natural reserve areas located on the outskirts of Greater Cairo (East and West of Greater Cairo), as shown in Fig. 1, became the only optimal and close environmental outlet for the people of Greater Cairo, and these reserves are represented in the Petrified Forest Protectorate, which is located at a distance of $30 \mathrm{~km}$ from
Cairo (East of Greater Cairo) and Hassanah Dome Protectorate, which is located at a distance of $23 \mathrm{~km}$ from Cairo (West of Greater Cairo) (EEAA, 2020). This is especially related to the Egyptian government's action in taking care to develop natural reserves to maximize the economic and investment return from them, with their sustainable use and preservation, through Egypt's 2030 vision for comprehensive sustainable development. The expansion of recreational activities and environmental tourism in these reserves may cause negative impacts on the natural and environmental constituents of these reserves, and thus necessitated a study of assessment and determination of the environmental carrying capacity of these reserves.

Fig. 1. The site of two protected areas on the outskirts of Greater Cairo

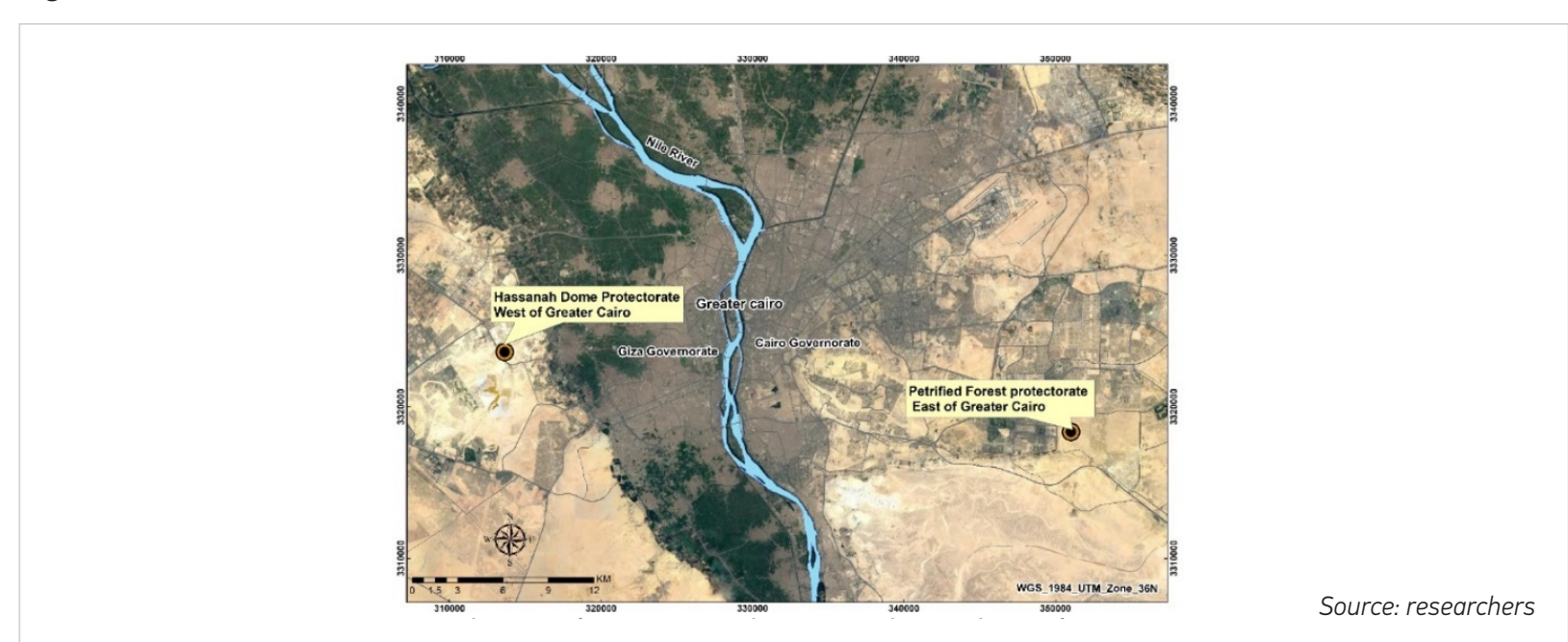


Both protectorates have many rare natural geological constituents, which attract visitors constantly, making it one of the most important ecotourism destinations. As for the Hassanah Dome Protectorate, as shown in Fig. 2 , it is considered a museum and a specialized scientific institute that helps in studying earth sciences and the various geological structures of folds and faults. It can also be compared with structures in other places. There is also a gathering of holes in fully preserved colonies that makes the Hassanah Dome an ideal area for the study of paleontology or ancient life science, as well as the features of the ancient environment and the extent of climate change that occurred in this region, especially during the upper cretaceous period, which characterized this area. The colonies of coral reefs fossil that characterized this area are the best guiding fossils that refer to the ancient environment, so these marine fossils represent a complete record of the ancient history (EEAA, 2020). Fig. 3 shows some characteristics of the Hassan Dome Protectorate, such as durrani colony and anticline.

Fig. 2. Hassanah Dome Protectorate

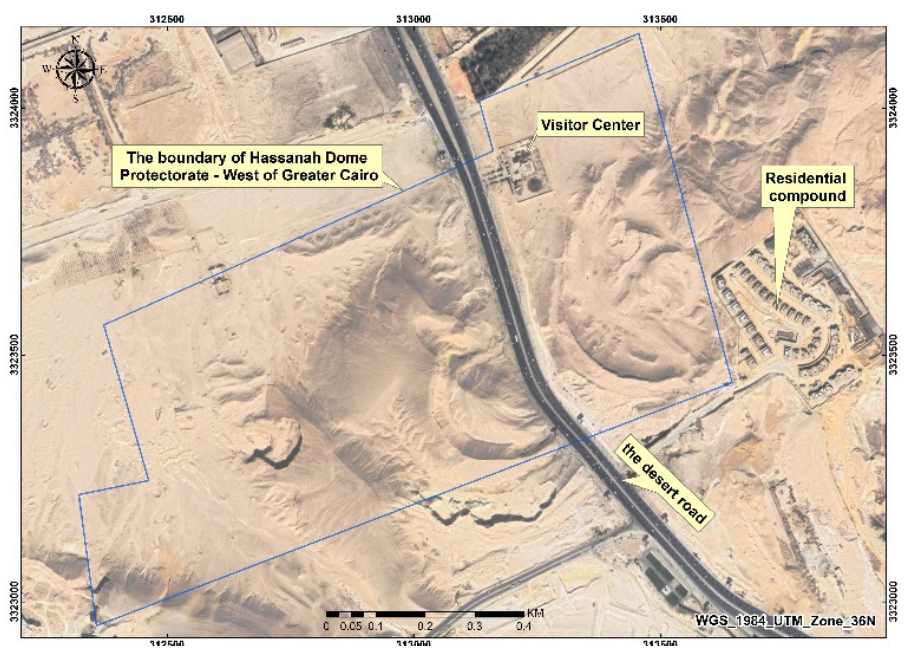

Source: researchers

Fig. 3. Some characteristics of the Hassan Dome Protectorate

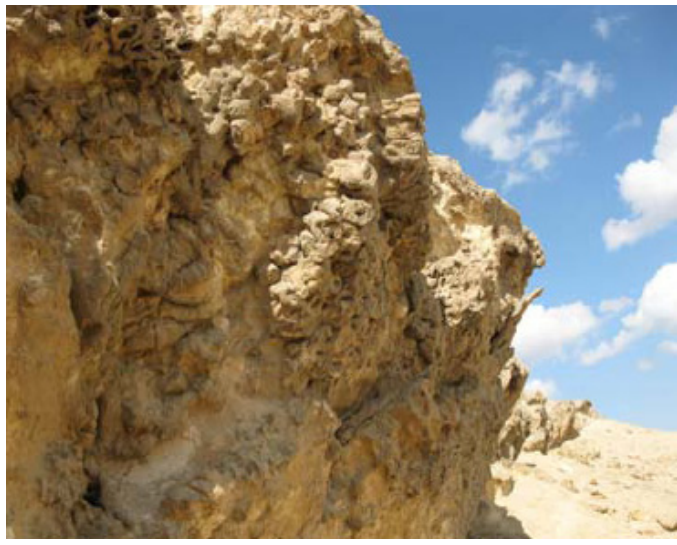

Durrani Colony

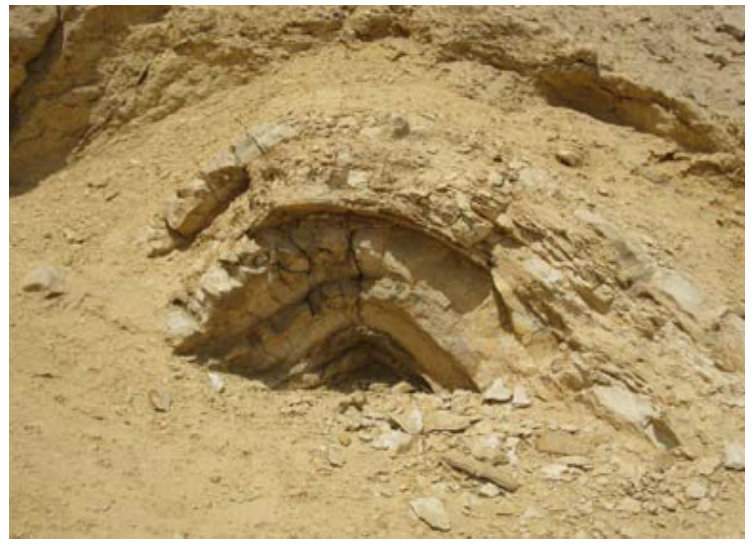

Anticline 
As for the Petrified Forest Protectorate, as shown in Fig. 4, the rocky wood area abounds with dense rocky stems of trees that contribute to the formation of the wood mountain that belongs to the Oligocene epoch. It consists of layers of sand, gravel, mud and rocky wood with a thickness of 70-100 meters. It is significantly rich with remains and stems of large rocky trees, taking the shape of rocks with cylindrical sections varying in dimension from a few centimeters up to several meters. They are grouped together in a rocky wood. Thus, the formation of the rocky wood is most probably attributed to one of the ancient branches of the River Nile from the ancient geological period that carried those trees along and threw them in that place where they were buried and changed into rocks (EEAA, 2020). Fig. 5 shows some models for fossils of the Petrified Forest Protectorate.

Fig. 4. Petrified Forest Protectorate

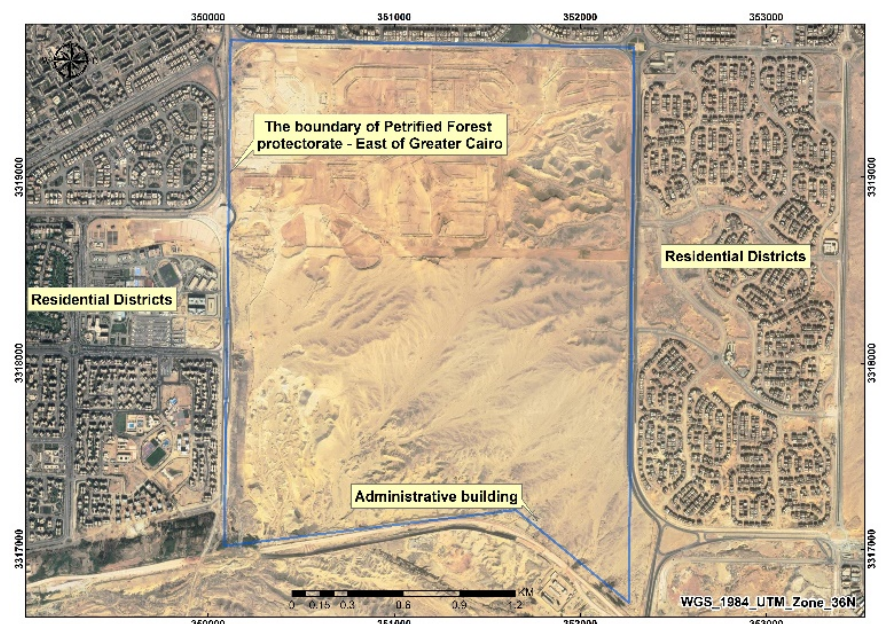

Source: researcher

Fig. 5. Some models for fossils of the Petrified Forest Protectorate.
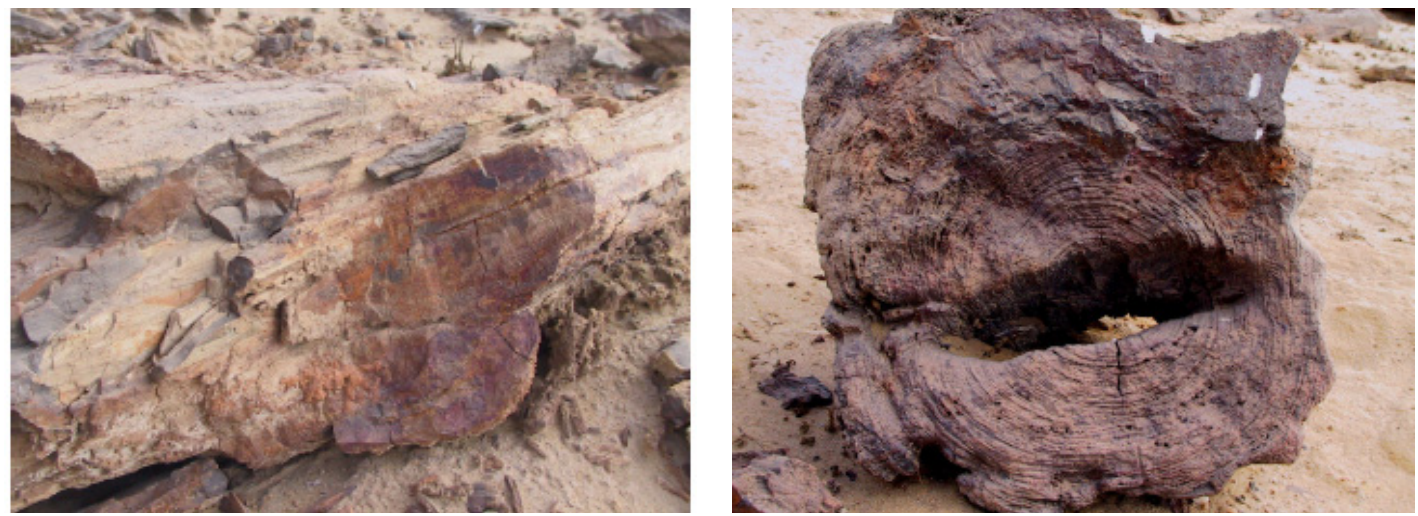

Source: researchers

The concept of carrying capacity was brought up by Thomas Malthus in 1798, who expected that the Earth could not hold only a specified amount of human growth for a specified period. He pointed out that this concept occupied an important position in determining the quality and condition of the system's environmental 
concerns in terms of pressure to meet the demands of the population, and it was basically an environmental concept that includes social and economic factors (ILPWRM, 2011; Seidl and Tisdell, 1999).

Through the researcher's review of previously available literature related to discussing and presenting definitions and concepts of carrying capacity and how to calculate it, the researcher found difficulties in determining carrying capacity as it is a very broad concept and related to multiple scientific disciplines that have different perspectives (social - economic - environmental - cultural - urban - tourism - institutional).

The environmental carrying capacity is a concept that emerged from the demographic, environmental, and biological sciences, and it refers to the environmental ability of any area to support the threshold of human activities with resources at a specific time (Li et al., 2019; Kang and Xu, 2012).

Besides, this concept indicates that there are limits to environmental and natural thresholds that should not be crossed so that environmental risks and damages do not occur irreversibly (Wei et al., 2015). Thus, the concept of environmental carrying capacity (ECC) forms the basis for multiple concepts derived from it, such as the environmental urban carrying capacity (EUCC) and the environmental tourism carrying capacity (ETCC).

According to the viewpoint of urban planners, the concept of urban environmental carrying capacity is the ability to absorb population growth without causing environmental impacts and damages. This concept indicates the maximum economic scope that can be supported by the environmental base. Also, this concept refers to the size of population growth, land uses and human activities, and urban development that can be strengthened from the urban environment without causing serious destruction and irreversible damage (Wei et al., 2015).

There are variables associated with the concept of urban environmental carrying capacity for any region, and they are population, natural resources that meet the needs of the population and human activities, waste generated from the population from solid waste, sewage waste, pollutants, and others, techniques, tools, and systems that are completed to exploit natural resources and the extent of the ecosystem's resilience in the face of environmental threats and pressures (Taiwo and Feyisara, 2017).
As for the concept of environmental tourism carrying capacity, the World Tourism Organization (WTO) defined it in 1981 as the maximum number of visitors who visit a tourism area at the same period without causing damage to the environmental, social, economic and cultural system in addition to not causing an unacceptable decrease in the quality of visitor satisfaction (Maggi and Fredella, 2010). The International Union for Conservation of Nature (IUCN) also emphasized this definition and stated that the environmental tourism carrying capacity is one of the axes of the tourism management framework in the protected areas; this framework is represented in limits of acceptable change, carrying capacity, recreation opportunity and setting standards in order to set goals and criteria for tourism in protected areas, monitor indicators, and take administrative decisions to correct the deficiencies (IUCN, 2018).

There is a more accurate definition of environmental tourism carrying capacity by discrimination between four different types, namely physical carrying capacity (PCC), psychological carrying capacity (PCCa), social carrying capacity, and economic carrying capacity. Physical carrying capacity (PCC) indicates the maximum site carrying capacity so that if it is overlooked, environmental problems appear (Rajan, 2011). Psychological carrying capacity (PCCa) indicates the least degree of feeling of tourists that keep them going and holding the recreational site and not looking for alternative tourism destinations (Rajan, 2011; Bonilla et al., 2008). Social carrying capacity indicates the level of tolerance of the host population to the presence of tourists and their behavior, and how willing the host population is to accept the congestion of tourism users (Rajan, 2011; Saveriades, 2000). Economic carrying capacity indicates the ability to attract activities of tourism without deactivating the desired local economy (Rajan, 2011).

The concept of environmental tourism carrying capacity provides a certain level of tourism activity and in case of exceeding the limits of this activity, it will result in the damage of the environment including natural habitats; meanwhile, the number of visitors usually indicates the level of change which can be acceptable regarding resource sustainability and social and economic user satisfaction (Maggi and Fredella, 2010).

The importance of assessing the environmental tourism carrying capacity for a destination appears by measuring 
and setting the threshold in which change due to tourism activities is rejected to the whole system, including natural and human resources. This concept also contributes well to developing local management plans and strategies for sustainable eco-tourism. It is a method for assessing the sustainability of the current conditions of any ecotourism destination (Castellani and Sala, 2012). All concepts refer mainly to not affecting environmental systems and not exceeding environmental limits.

\section{Materials and Methods}

Analysis of the basic and common concepts of environmental carrying capacity demonstrated that this concept was confined between two methods. The first method, which is the number or the quantitative method is used as an attempt to measure the number of people that can be absorbed by any ecosystem without causing any deterioration or destruction in it, and use it in determining the extent of absorbing the population growth rates. The second method, which is the descriptive method, aims to describe the degree, level, and quality of human activities (urban tourism, etc.) that can be absorbed by any ecosystem without any deterioration or destruction.

In order to evaluate the environmental carrying capacity, this requires specifying the human activity to be evaluated. The evaluation methodology should be carried out in the framework of two main axes, namely, the supporting environmental capacity and the assimilative environmental capacity (U.S EPA, 1974).

\section{The model used}

The model used to assess the environmental tourism carrying capacity of Petrified Forest Protectorate and Hassanah Dome Protectorate is represented in the methodology used by the International Union for Conservation of Nature (IUCN, 1996). Many studies that apply this methodology have been widely reviewed, such as (Amiry et al., 2013; Gupta et al., 2018; Maji, 2018; Ortega et al., 2011; Sari and Rahayu, 2018; Somarriba et al., 2006; Sayan and Atik, 2011; Zacarias et al., 2011; Ar Salan et al., 2018; Daneshvar et al., 2017). This methodology is represented in three levels, namely physical carrying capacity (PCC), real carrying capacity (RCC), and effective carrying capacity (ECC). Each level is more than the next level, meaning that it is always PCC > RCC $\geq E C C$, with the addition of the ecological carrying capacity index (ECCl) (Maji, 2018).

\section{Physical carrying capacity (PCC)}

The first level, physical carrying capacity (PCC), is the maximum number of visitors that can actually commensurate with a specific area during a specific time period. And it is expressed through the following formula:

$\mathrm{PCC}=\mathrm{A} / \mathrm{AV} * \mathrm{RF}$

Where: A - Area available in a specific area; AV - The Area required for each visitor $\left(\mathrm{m}^{2}\right)$; RF - Rotation Factor (the number of allowable daily visits).

According to the World Health Organization (WHO), the required space for each person is 9.5 square meters (Maji, 2018). The rotation factor (RF) is the number of allowable daily visits to a specific area and is determined by this formula, RF = the open period of the specific area/ average time per visit.

\section{Real carrying capacity (RCC)}

The second level, real carrying capacity (RCC), is the maximum allowable number of visits to a specific area. It is calculated once the corrective (i.e., reductive) factors derived from the certain characteristics of the area have been applied to the PCC. These corrective factors are obtained by considering environmental, social, biophysical, ecological, and management variables; in other words, the variables that cause the disruption of tourism movement or prevent visits to recreational environmental areas.

These variables may be in excessive sunshine, rainfall, erosion, accessibility, disturbance to wildlife, temporary closing of sites, dust storms, and any other variables. It is not necessary that all variables or corrective factors are present in one site, as the corrective factors stem from the specific circumstances and characteristics of each site. And it is expressed through the following formula:

$\mathrm{RCC}=\mathrm{PCC} *(\mathrm{Cf} 1 * \mathrm{Cf} 2 * \mathrm{Cf} 3 \ldots . \mathrm{Cfn})$

Where: PCC - Physical Carrying Capacity; Cf - Correction Factors. 
The following formula is used to calculate corrective factors:

$\mathrm{Cf}=1-\mathrm{Lvx} / \mathrm{Tvx}$

Where: $C f=$ corrective factor; $L v x=$ limiting value of the variable; Tvx = Total value of the variable.

\section{Effective carrying capacity (ECC)}

The third level, effective carrying capacity (ECC), is the maximum number of visitors that a specific area can support, given the available operational and management capacity (MC). The effective carrying capacity is obtained by comparing real carrying capacity (RCC) with the management capacity (MC) of the specific area administration.

It is not easy to measure the management capacity (MC) as it is determined by the total of several requirements, i.e., the infrastructure and employees (number, qualifications), equipment, services, activities, financing, legislative and institutional framework, and other administrative and operational aspects. And it is expressed through the following formula:

$\mathrm{ECC}=\mathrm{RCC} \times \mathrm{MC}$

Where: RCC - Real Carrying Capacity; MC - Management capacity.

According to the example provided by the International Union for Conservation of Nature, in the Carara Biological Reserve, it will be considered that the administrative capacity is 15\% (IUCN, 1996).

\section{Ecological carrying capacity index (ECCI)}

The ecological carrying capacity index (ECCl) is the site functional assessment index of the extent of population support and activities. And it is expressed through the following formula:

$$
\mathrm{ECCI}=\mathrm{ECC} / \mathrm{P}
$$

Where: ECC - Effective Carrying Capacity; P - Population of the urban area (Great Cairo).

The ECCI has an index value where:

$<1$ refers to the ecological capacity that is not enough;

$>1$ refers to the ecological capacity that is enough.

\section{Collection of data and calculation}

The data were divided according to the requirements of each level of methodology for calculating the environmental tourism carrying capacity that was previously explained, as follows.

\section{Physical carrying capacity data}

The area of the Petrified Forest Protectorate in East Greater Cairo is $7 \mathrm{~km}^{2}$, and the area of the Hassanah Dome Protectorate in the West of the Greater Cairo is $1 \mathrm{~km}^{2}$ (EEAA, 2020). Through the field visit to the two protectorates, it was found that the period was open for both protectorates for 8 hours, i.e., from 8 AM until 4 $\mathrm{PM}$ on all days of the week. It was also found that the average time of one visit for one visitor was 4 hours. As previously explained, according to the World Health Organization (WHO), the required space for each person is 9.5 square meters (Maji, 2018).

By applying the physical carrying capacity formula (1), PCC=A / AV * Rf, and using the data in Table 1, for Petrified Forest Protectorate, $\mathrm{PCC}=7,000,000 / 9.5^{\star} 2=$ 1,473,684 visitor/day, and for Hassanah Dome protectorate, $P C C=1,000,000 / 9.5^{\star} 2=210,526$ visitor $/$ day.

\section{Real carrying capacity data}

Environmental variables and correction factors are the same for both protectorates and as previously explained as the environmental conditions that hinder or disrupt the visit of the two protectorates. Those variables are represented by the high temperature and the heavy rainfall.

Table 1. The data required to calculate the physical carrying capacity of the two protectorates

\begin{tabular}{l|c|c|c|c|c}
\hline $\begin{array}{c}\text { The name of the } \\
\text { protectorate }\end{array}$ & Area (A), $\mathrm{m}^{2}$ & $\begin{array}{c}\text { Open period, } \\
\text { hours }\end{array}$ & $\begin{array}{c}\text { Average time per } \\
\text { visit, hours }\end{array}$ & $\begin{array}{c}\text { Rotation factor (RF), } \\
\text { visits/day }\end{array}$ & $\begin{array}{c}\text { The area required for each } \\
\text { visitor (AV), } \mathrm{m}^{2}\end{array}$ \\
\hline $\begin{array}{l}\text { Petrified Forest } \\
\text { Protectorate }\end{array}$ & $7,000,000$ & 8 & 4 & 2 & 9.5 \\
\hline $\begin{array}{l}\text { Hassanah Dome } \\
\text { Protectorate }\end{array}$ & $1,000,000$ & 8 & 4 & 2 & 9.5 \\
\hline
\end{tabular}


The Great Cairo weather is characterized by being always moderate, but with the conditions of climate change in the recent period, Greater Cairo was affected by this climate change. Through a field survey with the management of the two protectorates to review the times when the two protectorates are visited and the times when they were not visited, and taking into consideration dealing with the worst cases, it was found that there is 30 days/year, which visits are severely reduced due to the high temperature, in July, and the presence of another 30 days in the year also reduces visits to them severely due to heavy rains, between January and February. The total value of the variable (Tvx) equals the number of days in a year $=365$ days, as shown in Table 2 .
By applying the real carrying capacity formula (2), RCC = $\mathrm{PCC}{ }^{*}\left(\mathrm{Cf} 1{ }^{*} \mathrm{Cf} 2\right)$, and using the data in Table 2, for Petrified Forest Protectorate, $\mathrm{RCC}=1,473,684^{*}\left(0.918^{*} 0.918\right)=$ $1,241,908$ visitor/day, while for Hassanah Dome Protectorate, $\mathrm{RCC}=210,526 *(0.918 * 0.918)=177,415$ visitor $/$ day.

\section{Effective carrying capacity data}

The effective carrying capacity is calculated from the formula (3), ECC $=$ RCC $\times M C$, using the results of calculating the real carrying capacity. As previously explained, management capacity will be considered $15 \%$; thus, for Petrified Forest Protectorate, ECC $=15^{\star} 1,241,908 / 100=$ 186,286 visitors/day, while for Hassanah Dome Protectorate, $\mathrm{ECC}=15^{\star} 177,415 / 100=26,612$ visitors $/$ day.

Table 2. The data required to calculate the real carrying capacity of the two protectorates

\begin{tabular}{l|c|c|c|c|c|c}
\hline $\begin{array}{l}\text { The name of the } \\
\text { protectorate }\end{array}$ & $\begin{array}{c}\text { Physical carrying } \\
\text { capacity }(\mathrm{PCC}), \\
\text { visitors/day }\end{array}$ & $\begin{array}{c}\text { Limiting value of the } \\
\text { variable }(\mathrm{Lvx})-\text { high } \\
\text { temperature, day }\end{array}$ & $\begin{array}{c}\text { Limiting value of } \\
\text { the variable }(\mathrm{Lvx}) \\
\text { - heavy rains, day }\end{array}$ & $\begin{array}{c}\text { Total value of } \\
\text { the variable } \\
\text { (Tvx), day }\end{array}$ & $\begin{array}{c}\mathrm{Cf}_{1}=1-\mathrm{Lvx}_{1} \\
/ \mathrm{Tvx}\end{array}$ & $\begin{array}{c}\mathrm{Cf}_{2}=1-\mathrm{Lvx}_{2} \\
/ \mathrm{Tvx}\end{array}$ \\
\hline $\begin{array}{l}\text { Petrified Forest } \\
\text { Protectorate }\end{array}$ & $1,473,684$ & 30 & 30 & 365 & 0.918 & 0.918 \\
\hline $\begin{array}{l}\text { Hassanah Dome } \\
\text { Protectorate }\end{array}$ & 210,526 & 30 & 30 & 365 & 0.918 & 0.918 \\
\hline
\end{tabular}

\section{Results and discussion}

The total effective carrying capacity of both protected areas reached 212,898 visitors per day. The effective carrying capacity of the Petrified Forest Protectorate in East Cairo amounted to 186,286 visitors today, which is greater than the effective capacity of Hassanah Dome Protectorate in West Cairo, which reached 26,612 visitors per day, as shown in Table 3, and Fig. 6.

By measuring the level of ecological carrying capacity index (ECCl) that measures the extent of the two protectorates' support to the population and their activities, it was found that the functional capacity was less than 1 , meaning that the carrying capacity of the two protectorates is insufficient to accommodate the population of the Greater Cairo to support their activities in the environmental and recreational tourism. As explained earlier, the ecological carrying capacity index $(\mathrm{ECCl})$ is expressed through formula (4): ECCl = ECC/P. For Petrified Forest Protectorate, $\mathrm{ECCl}=186,286 / 17,000,000=0.0109$, while for Hassanah Dome Protectorate, $\mathrm{ECCl}=26,612 / 17,000,000=0.0015$, as shown in Table 4, and Fig. 7.

Table 3. Environmental tourism carrying capacity of the two protectorates

\begin{tabular}{l|c|c|c}
\hline \multicolumn{1}{|c|}{ The protectorate } & PCC, visitors/day & RCC, visitors/day & ECC, visitors/day \\
\hline Petrified Forest Protectorate & $1,473,684$ & $1,241,908$ & 186,286 \\
\hline Hassanah Dome Protectorate & 210,526 & 177,415 & 26,612 \\
\hline Total & $1,684,210$ & $1,419,323$ & 212,898 \\
\hline
\end{tabular}


Fig. 6. Environmental carrying capacity levels of the two protectorates

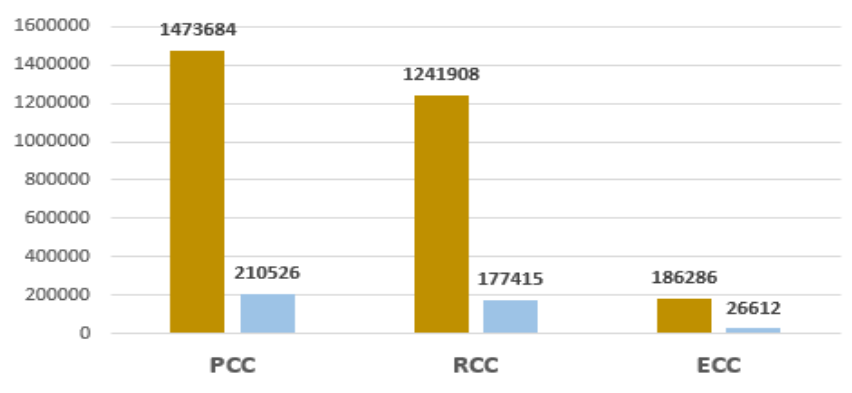

- Petrified Forest Protectorate Hassanah Dome protectorate

Table 4. Ecological carrying capacity index of the two protectorates

\begin{tabular}{l|c|c|c}
\multicolumn{1}{c|}{ The protectorate } & Effective carrying capacity (ECC), visitors/day & Population (P) & Class ECCI \\
\hline Petrified Forest Protectorate & 186,286 & $17,000,000$ & Low $<1$ \\
\hline Hassanah Dome Protectorate & 26,612 & $17,000,000$ & Low $<1$ \\
\hline Total & 212,898 & $17,000,000$ & Low $<1$ \\
\hline
\end{tabular}

Fig. 7. Ecological carrying capacity index (ECCI) of the two protectorates

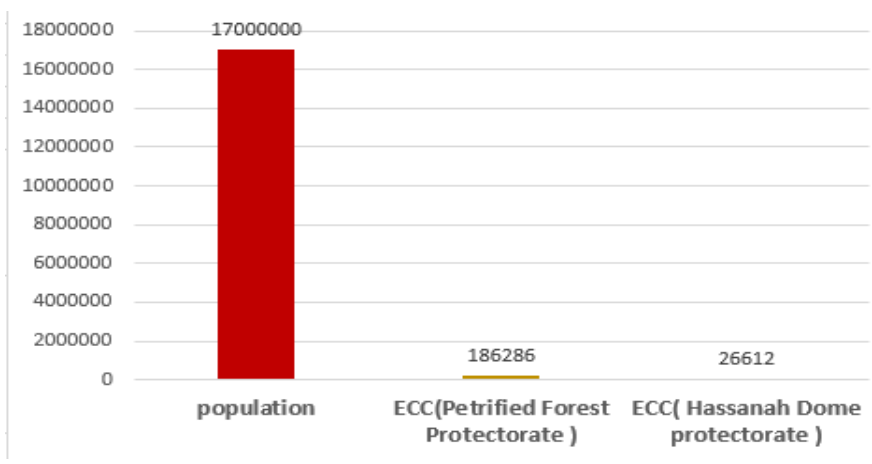

\section{Conclusions}

The importance of assessing the environmental carrying capacity of natural reserves or eco-tourism areas appears to be one of the tools for achieving sustainability and preserving natural resources and adopting them as a method for sustainable environmental management as it works as a measure to maintain the environmental balance between meeting human needs and the continuity of natural resources and not depleting them. This is evidenced by the focus of the research on assessing the environmental carrying of two natural reserves in the Greater Cairo, which suffers from a high population density, to set limits for recreational and tourism use of these reserves, which are the maximum and the optimal number of visitors who can visit the reserve 
without affecting them negatively. The optimum limit has reached 212,898 visitors per day for both protectorates. These limits should not be exceeded so that natural resources are not destroyed and to ensure the continuity and sustainability of these natural resources.

In the current situation, the two protectorates (Hassanah Dome Protectorate and Petrified Forest Protectorate) do not face any problems with the number of visitors, as the number of visitors is very small for both protectorates, due to the weak culture of ecotourism in protectorates among the population.

According to the field survey data with the management of the two protectorates, in 2019, the number of visitors to the Hassanah Dome Protectorate reached 850 visitors per year, and the number of visitors to the Petrified Forest Protectorate reached 970 visitors per year. This is a very small percentage compared to the results of the research for the environmental carrying capacity of both protectorates, as the results of the research show that the Petrified Forest Protectorate (East of Greater Cairo) accommodates 186,286 visitors per day, and the Hassanah Dome Protectorate (West of Greater Cairo) accommodates 26,612 visitors per day.

However, due to the Egyptian government's interest in developing natural reserves within Egypt's 2030 vision for sustainable development by setting up a future plan to support environmental tourism in protected areas and opening up investment through the establishment of tourism activities, these two protectorates may face in the future high pressure through the increase in the number of local and foreign visitors. These two protectorates are located on the outskirts of the Greater Cairo, which is characterized by high population pressure and rapid urban growth, which may expose it to attrition or deterioration and the occurrence of environmental damage.

Therefore, the research proposes the necessity of adopting the concept of environmental carrying capacity as a method for sustainable environmental management of the Hassanah Dome Protectorate and Petrified Forest Protectorate under the open field of investment and establishment of tourism activities, which will lead to an increase in the number of tourists.

Also, the research recommends applying the methodology used for all protected areas in Egypt, as it is rich in 30 protected areas, a percentage exceeding $15 \%$ of the total area of Egypt (EEAA, 2020). Generally, the research concludes that environmental carrying capacity should be taken as a sustainable strategic planning approach to environmental and urban planning processes for any site and any region.

\section{References}

Alexis Saveriades. (2000) Establishing the social tourism carrying capacity for the tourist resorts of the east coast of the Republic of Cyprus. Tourism Management 21:147-156. Available at: https://dokumen.tips/documents/establishing-the-social-tourism-carrying-capacity-for-the-tourist-resorts-of.html https://doi.org/10.1016/S0261-5177(99)00044-8

Arpit Gupta., Aman Gupta. and D.Jyothsna. (2018) Assessment of Carrying capacity of tourist destinations in The Nilgiris district. India. IARJSET, 5 (3):118-121. Available at: https://iarjset. com/upload/2018/march-18/IARJSET\%2020.pdf

Brilliant Rajan. (2011) Assessment of carrying capacity of selected tourism destinations in Kerala. PHD , Chapter-II, pp 38, Mahatma Gandhi University , India. Available at: http://shodhganga.inflibnet.ac.in:8080/jspui/handle/10603/25951 (accessed 26 September 2014).

CAPMAS (Central Agency for Public Mobilization and Statistics) (2017) Population census, Egypt.
Chandra Puspita Sari., Sri Rahayu. (2018) Carrying Capacity of Gancik Hill Top for Ecotourism Development in Boyolali District. Indonesia. The 3rd International Conference on Energy, Environmental and Information System 73, 02008 (2018). Available at: https://www.e3s-conferences.org/articles/e3sconf/pdf/2018/48/e3sconf_icenis18_02008.pdf https://doi. org/10.1051/e3sconf/20187302008

Daniel A. Zacarias., Allan T. Williamsand and Alice Newton. (2011) Recreation carrying capacity estimations to support beach management at Praia de Faro, Portugal. Applied Geography, 31:1075-1081. Available at: https://core.ac.uk/ download/pdf/61500076.pdf https://doi.org/10.1016/j.apgeog.2011.01.020

EEAA (Egyptian Environmental Affairs Agency) (2020) Natural Protectorates Description. Available at: http://www.eeaa.gov. eg/en-us/topics/nature/protectorates/protectoratesdescription.aspx 
Elena Maggi., Franco Lorenzo Fredella. (2010) The carrying capacity of a tourism destination, The case of a coastal Italian city. Italy. 50th Congress of the European Regional Science Association: "Sustainable Regional Growth and Development in the Creative Knowledge Economy”, Jönköping, Sweden.19-23 August 2010, pp 3. Available at: https://www.econstor.eu/bitstream/10419/118917/1/ERSA2010_0576.pdf

Famutimi John Taiwo., Oni Oluwasola Feyisara. (2017) Understanding the Concept of Carrying Capacity and its Relevance to Urban and Regional Planning. Nigeria. Journal of Environmental Studies 3(1): 2. Available at: https://www.avensonline.org/ wp-content/uploads/JES-2471-4879-03-0017.pdf

ILPWRM (Integrated Land use Planning \& Water Resources Management) (2011-2012) Urban Carrying Capacity Concept \& Calculation, Department of Civil Engineering, IIT Guwahati, India, pp 3. Available at: https://www.scribd.com/document/353686453/Urban-Carrying-Capacity-pdf

Irmi Seidl and Clement Allan Tisdell. (1999) Carrying Capacity Reconsidered: From Malthus' Population Theory to Cultural Carrying Capacity. Switzerland, Australia. Ecological Economics (ECOL ECON), 31(3):395-408. Available at: https://www.researchgate. net/publication/222506604_Carrying_Capacity_Reconsidered_ From_Malthus'_Population_Theory_to_Cultural_Carrying_Capacity https://doi.org/10.1016/S0921-8009(99)00063-4

IUCN (the International Union for Conservation of Nature) (2018) Tourism and visitor management in protected areas. pp 28-35. Available at: https://portals.iucn.org/library/node/47918

IUCN (the International Union for Conservation of Nature) (1996) Tourism, ecotourism, and protected areas . Available at: https:// portals.iucn.org/docs/library/html/Tourism/cover.html

Jesús Manuel López-Bonilla and Luis Miguel López-Bonilla. (2008) Measuring Social Carrying Capacity: An Exploratory Study. Spain. TOURISMOS: AN INTERNATIONAL MULTIDISCIPLINARY JOURNAL OF TOURISM, 3 (1):116 -134. Available at:

https://www.researchgate.net/publication/47716079_Measuring_Social_Carrying_Capacity_An_Exploratory_Stud

José Luis Cornejo Ortega., Rosa María Chávez Dagostino and Amílcar Leví Cupul Magaña. (2011) Estimating carrying Capacity in a natural protected area as a conservation strategy. Mexico. Conference: Impact Assessment and Responsible Development, at Puebla, Mexico. Available at:

https://www.researchgate.net/publication/271197162_ESTIMATING_CARRYING_CAPACITY_IN_A_NATURAL_PROTECTED_AREA_AS_A_CONSERVATION_STRATEGY

Kaiyuan Li., Xiaolong Jin. Danxun Ma and Penghui Jiang . (2019) Evaluation of Resource and Environmental Carrying Capacity of China's Rapid-Urbanization Areas-A Case Study of Xinbei District, Changzhou.China. Land 8 (69): 1. Available at: https://doi. org/10.3390/land8040069
https://www.researchgate.net/publication/332585522_Evaluation_of_Resource_and_Environmental_Carrying_Capacity_ of_China's_Rapid-Urbanization_Areas-A_Case_Study_of_Xinbei_District_Changzhou

Masoumeh Amiry Lagmoj., Dr. Abdolkarim Keshacarz Shokry. Dr. Seyed Armin Hashemi. and Dr. Hasam Karim Zadegan. (2013) Defining the Ecotourism Carrying Capacity of Langeroud City (Case Study: Khorma Forest). Iran. Greener Journal of Social Sciences, 3(9):447-457. Available at: https://doi. org/10.15580/GJSS.2013.9.100613886

https://www.gjournals.org/GJSC/GJSC\%20PDF/2013/November/100613886\%20Lagmoj\%20et\%20al.pdf

Md. Shakil Ar Salan., Tofael Ahmed and Md. Abdul Wakil. (2018) The Assessment of Physical and Real Carrying Capacity for the Promotion of Sustainable Tourism in Rajshahi. Bangladesh. Advances in Economics and Business Management (AEBM), 5:47-51. Available at:

https://www.researchgate.net/publication/324656981_The_ Assessment_of_Physical_and_Real_Carrying_Capacity_for_ the_Promotion_of_Sustainable_Tourism_in_Rajshahi_A_ Study_of_Padma_River_Bank

Mohammad Reza Mansouri Daneshvar., Fahimeh Khatami and Farzin Zahed. (2017) Ecological carrying capacity of public green spacesas a sustainability index of urban population: a case studyof Mashhad city in Iran. Modeling Earth Systems and Environment, 3 (3):1161-1170. Available at: https://doi. org/10.1007/s40808-017-0364-2

https://www.researchgate.net/publication/319114838_Ecological_carrying_capacity_of_public_green_spaces_as_a_sustainability_index_of_urban_population_a_case_study_of_ Mashhad_city_in_Iran

M. Somarriba-Chang., M. Garnier and V. Laguna. (2006) Estimation of the tourist carrying capacity of the Natural Reserve Mombacho Volcano, Granada, and the Natural Reserve Datanlí-El Diablo, Jinotega, Nicaragua. Sustainable Tourism II (97):341-351. Available at: https://www.witpress.com/ Secure/elibrary/papers/ST06/ST06032FU1.pdf https://doi. org/10.2495/ST060321

Mustafa Selcuk SAYAN., Meryem ATIK. (2011) Recreation Carrying Capacity Estimates for Protected Areas: A Study of Termessos National Park. Turkey. Ekoloji, 20 (78):66-74. Available at: https://doi.org/10.5053/ekoloji.2011.7811

http://www.ekolojidergisi.com/download/recreation-carrying-capacity-estimates-for-protected-areas-a-study-of-termessos-national-park.pdf

Peng Kang., Linyu Xu. (2012) Water Environmental Carrying Capacity Assessment of an Industrial Park. China. Procedia Environmental Sciences 13:879-890. Available at: https://doi. org/10.1016/j.proenv.2012.01.082 
https://www.researchgate.net/publication/257728555_Water_Environmental_Carrying_Capacity_Assessment_of_an_Industrial_Park

Sougata Maji. (2018) Assessment of the carrying capacity of the green spaces in Asansol city. India. International Journal of Research and Analytical Reviews 5 (4):361-369. Available at:

https://ijrar.com/upload_issue/ijrar_issue_20542384.pdf

U.S.EPA (United States. Environmental Protection Agency) (1974) Carrying Capacity in Regional Environmental Management, pp 47. Available at: https://nepis.epa.gov/Exe/ZyPDF. cgi/9101BPXJ.PDF?Dockey=9101BPXJ.PDF

Valentina Castellani., Serenella Sala. (2012) Carrying Capacity of Tourism System: Assessment of Environmental and Manage- ment Constraints Towards Sustainability. p 298, Italy. Available at: https://doi.org/10.5772/38750

https://www.researchgate.net/publication/224830369_Carrying_Capacity_of_Tourism_System_Assessment_of_Environmental_and_Management_Constraints_Towards_Sustainability Yigang Wei., Cui Huang. Patrick T. I. Lam Yong Sha and Yong Feng. (2015) Using Urban-Carrying Capacity as a Benchmark for Sustainable Urban Development: An Empirical Study of Beijing. China. Sustainability, 7:3244-3268. Available at: https://doi. org/10.3390/su7033244

https://www.researchgate.net/publication/276884502_Using_UrbanCarrying_Capacity_as_a_Benchmark_for_Sustainable_Urban_Development_An_Empirical_Study_of_Beijing 